\title{
Relationship between E. coli and Toxicant Contamination in Primary School Canteen Food based on Region and Level in Surabaya, 2017
}

\section{Alda Dini Wijayanti ${ }^{1}$, Linda Dewanti ${ }^{*}$, Ema Qurnianingsih ${ }^{3}$}

\author{
${ }^{1}$ Faculty of Medicine, Universitas Airlangga, Surabaya, Indonesia. \\ 2 Department of Public Health, Faculty of Medicine, Universitas Airlangga, Surabaya, Indonesia. \\ ${ }^{3}$ Department of Biochemical, Faculty of Medicine, Universitas Airlangga, Surabaya, Indonesia.
}

\begin{abstract}
A B S T R A C T
Introduction: Primary students are still in the developing phase, so they still need enough nutrition. The food source they consume is not only originated from home but also from school snacks. However, it can be said that school snacks can be easily contaminated by E.coli and Hazardous and Toxic Substances (HTS) or toxicant. School plays a major role to regulate the canteen. Therefore, this study aims to know whether there is a relation between the monitoring and controlling of school snacks which E.coli and toxicant free food and the relation of the contaminated foods with the school zone and school status.
\end{abstract}

Methods: This research was conducted with analytics study from secondary datum from the result of the snacks investigation by the Public Health Office of Surabaya on primary school in 2017.

Results: The results of this study stated that there is no relationship between E.coli contamination in snacks and cooking utensils and toxicant contamination in snacks with the school region and status in Surabaya.

Conclusion: It is needed to enhance the supervision of the school especially for primary school to increase healthy food in school canteen whether it is public school or private school.

* Correspondence: lindaperisdiono@yahoo.com

JUXTA: Jurnal IImiah Mahasiswa Kedokteran Universitas Airlangga

p-ISSN: 1907-3623; e-ISSN: 2684-9453

DOI: $10.20473 /$ juxta.V11/12020.9-12

Open access under Creative Commons Attribution-ShareAlike 4.0 International License (CC-BY-SA)
ARTICLE INFO

\author{
Article history: \\ Received 27 November 2019 \\ Received in revised form 07 \\ January 2020
}

Accepted 24 January 2020

\section{Keywords:}

Toxicant,

E. coli,

School canteen. 


\section{Introduction}

Primary students are the children who are still in the developing phase, so that sufficient nutrients are needed for growth and development. In students, breakfast is still a priority in their nutritional intake, but it only reaches $1 / 3$ of the nutritional needs. So, snacks need to fulfil their nutrition. ${ }^{1}$ School snacks contribute $20-31.1 \%$ to fulfil their daily energy, but $45 \%$ do not fulfil the requirements because they contain various harmful substances. From the research in Semarang, the students almost do routine snacks 2-3 times every day, this is supported by weak supervision from the school and a large fund. ${ }^{2}$

From the survey in Batu, there are many snacks which contain hazardous substances like formalin (71.4\%), borax $(23.5 \%)$, and rhodamine B $(18.5 \%){ }^{2}$ These substances can influence the normal development system and the susceptible from disease. ${ }^{3}$ Rhodamine $B$ is a prohibited dye that is often found in food. This substance can cause respiratory tract infection, skin irritation, eye irritation, liver cells necrosis, ${ }^{4}$ and also can cause glomerular damage and tubular cirrhosis according to the dose and the duration of administration. $^{5}$ Borax can cause nausea, vomiting, diarrhoea, stomach cramps, anxiety, and kidney damage. ${ }^{6}$ Formalin can cause genetic mutations and cancer. ${ }^{2}$ Rhodamine $\mathrm{B}$, borax, and formalin can be called as toxicant. E.coli can cause diarrhoea depends on their type. ${ }^{7}$

In Indonesia, BPOM is the national organizer to improve the safety, nutrition, and quality of foods, one of them is PJAS or school snacks. ${ }^{1}$ Beside that, many sectoral help and in synergy with BPOM, such as Ministry of Health, Ministry of Education, Puskesmas, and UKS (School Health) team to control the quality of snacks in the school canteen. The documentation of the food and canteen quality will be recorded by UKS teacher and will be monitored by the Puskesmas every 6 months. ${ }^{8}$ The school has an urgent role in managing all activities related to snack quality and security in school. So, the school must make regulations and contract to the canteen vendor. ${ }^{8}$ Beside the supervision, it also requires an appreciation both of reward and punishment so that the supervision is reciprocal. ${ }^{9}$ Good implementation of nutrition issues in the school canteen in providing food according to health standards can be realized with the help of various parties

This study aims to determine the relationship of the school snacks quality from the shelf (toxicant and E.coli) with the school control in primary school. It is expected that after this research, the healthy level of the food can be increased, as well as the school control in primary school about the canteen food, and also make another effort to keep the quality, nutrient, and safety of the food in primary school.

\section{Methods}

This was analytical studies by collecting secondary data. The data was obtained from the Public Health Service of Surabaya from food screening in school canteens. The criteria of sample in this study was elementary schools that had been tested for snacks and were trained by Public Health Service of Surabaya and were tested and coached in 2017. The free variable was the quality of school snacks that were free of toxicant and E.coli. The bound variables were school policies related to school canteens (licensing and provisions regarding peddlers, snacks, and street vendors), management of the school canteen, the organizational structure of the supervisor of the school canteen, extension and guidance programs for students and peddlers, monitoring and reporting, appreciation and reward.
The research instrument used secondary data from laboratory test of canteen school in Surabaya obtained from screening by Surabaya Public Health Service (DKK). Snack quality was checked from toxicant and E.coli with these equipment: formalin with sulphuric solution formaldehyde reacts with chromatophic acid, borax with colorimetric determination with turmeric paper (MN.907.47), Rhodamine B with spectrophotometer UV-Vis with lambda $538 \mathrm{~nm}$, and E.coli with MPN test (Most Probable Number) with Lactose Broth media, Brillian Green Lactose Bile Broth media, and MacConkey agar. Beside the secondary data, this study also used primary data with questionnaire, with 2 choices, yes or no. This research was conducted in Surabaya Public Health Service and elementary schools that had been tested and fostered in Surabaya. The collected data was processed using SPSS with chi square method.

\section{Results}

In this study, there are several things that were analyzed. The results of this study were obtained from secondary data from the Surabaya Public Health Service regarding the results of snacks tests at primary schools levels with private and public status.

\section{Quality of Snacks at Schools by Region}

In analyzing the quality of snacks in schools, it can be analyzed based on the location of the school which is divided into 5 regions. The schools analyzed include all elementary, junior high, and high schools both public and private. The quality of snacks was compared to $E$. coli contamination in snacks and equipment used for cooking and sprinkling toxicant. These differences were tested using the chi-square test as follows:

Table 1. E.coli contamination in primary school snacks based on the region in Surabaya.

\begin{tabular}{llllll}
\hline & \multicolumn{2}{l}{ E.coli contamination in snacks } & $\mathrm{p}$ \\
\cline { 2 - 4 } & \multicolumn{2}{l}{ Negative } & \multicolumn{2}{l}{ Positive } & \\
\cline { 2 - 5 } & Total & $\%$ & Total & $\%$ & \\
\hline $\begin{array}{l}\text { Central } \\
\text { Surabaya }\end{array}$ & 7 & $17.5 \%$ & 3 & $17.6 \%$ & 0.332 \\
\hline East Surabaya & 17 & $42.5 \%$ & 7 & $41.2 \%$ & \\
\hline West Surabaya & 4 & $10 \%$ & 5 & $29.4 \%$ \\
\hline North Surabaya & 8 & $20 \%$ & 1 & $5.9 \%$ & \\
\hline South Surabaya & 4 & $10 \%$ & 1 & $5.9 \%$ \\
\hline Total & 40 & $100 \%$ & 17 & $100 \%$ &
\end{tabular}

Table 2. E.coli contamination in primary school cooking tools based on the region in Surabaya.

\begin{tabular}{|c|c|c|c|c|c|}
\hline & \multicolumn{4}{|c|}{$\begin{array}{l}\text { E.coli contamination in cooking } \\
\text { tools }\end{array}$} & \multirow[t]{3}{*}{$p$} \\
\hline & \multicolumn{2}{|c|}{ Negative } & \multicolumn{2}{|c|}{ Positive } & \\
\hline & Total & $\%$ & Total & $\%$ & \\
\hline $\begin{array}{l}\text { Central } \\
\text { Surabaya }\end{array}$ & 9 & $19.6 \%$ & 0 & $0 \%$ & 0.074 \\
\hline East Surabaya & 22 & $47.8 \%$ & 1 & $20 \%$ & \\
\hline West Surabaya & 6 & $13 \%$ & 3 & $60 \%$ & \\
\hline North Surabaya & 5 & $10.1 \%$ & 0 & $0 \%$ & \\
\hline South Surabaya & 4 & $8.6 \%$ & 1 & $20 \%$ & \\
\hline Total & 46 & $100 \%$ & 5 & $100 \%$ & \\
\hline
\end{tabular}


Table 3. Toxicant contamination in primary school snacks based on the region in Surabaya.

\begin{tabular}{|c|c|c|c|c|c|}
\hline & \multirow{2}{*}{\multicolumn{2}{|c|}{$\begin{array}{l}\text { Toxicant } \\
\text { snacks } \\
\text { Negative }\end{array}$}} & \multicolumn{2}{|c|}{ contamination in } & \multirow[t]{3}{*}{$p$} \\
\hline & & & \multicolumn{2}{|c|}{ Positive } & \\
\hline & Total & $\%$ & Total & $\%$ & \\
\hline $\begin{array}{l}\text { Central } \\
\text { Surabaya }\end{array}$ & 3 & $18.8 \%$ & 4 & $14.3 \%$ & 0.374 \\
\hline East Surabaya & 9 & $56.2 \%$ & 13 & $46.4 \%$ & \\
\hline West Surabaya & 0 & $0 \%$ & 4 & $14.3 \%$ & \\
\hline North Surabaya & 2 & $12.5 \%$ & 6 & $21.4 \%$ & \\
\hline South Surabaya & 2 & $12.5 \%$ & 1 & $3.6 \%$ & \\
\hline Total & 16 & $100 \%$ & 28 & $100 \%$ & \\
\hline
\end{tabular}

Based on the test results using chi square test, it was obtained $p>0.05$, so it can be concluded that there is no difference between microbial and toxicant contamination in school snacks, cooking utensil, and school area. Based on the descriptive data, a lot of toxicant contamination in snacks in primary schools in Surabaya was found.

\section{Quality of Snacks at Schools by Status}

It compared the quality of snacks in school canteens and the status. The schools analyzed include all primary schools both public and private. The quality of snacks was compared to $E$. coli contamination in snacks and equipment used for cooking and sprinkling toxicant. In each contamination, a chi-square test was conducted to determine whether the school status had an effect on contamination in school snacks. These differences were tested using the chi-square test as follows:

Table 4. E.coli contamination of snacks, cooking utensils and toxicant contamination in snacks based on the school status.

\begin{tabular}{|c|c|c|c|c|c|}
\hline & \multicolumn{4}{|c|}{ E.coli contamination in snacks } & \multirow[t]{3}{*}{$\mathrm{p}$} \\
\hline & \multicolumn{2}{|l|}{ Positive } & \multicolumn{2}{|c|}{ Negative } & \\
\hline & Total & $\%$ & Total & $\%$ & \\
\hline Private & 3 & $18.7 \%$ & 16 & $40 \%$ & 0.211 \\
\hline Public & 13 & $81.3 \%$ & 24 & $60 \%$ & \\
\hline \multirow[t]{4}{*}{ Total } & 16 & $100 \%$ & 40 & $100 \%$ & \\
\hline & \multicolumn{4}{|c|}{ E.coli contamination in cooking tools } & $\mathrm{p}$ \\
\hline & \multicolumn{2}{|l|}{ Positive } & \multicolumn{2}{|c|}{ Negative } & \\
\hline & Total & $\%$ & Total & $\%$ & \\
\hline Private & 2 & $40 \%$ & 15 & $34.1 \%$ & 1,000 \\
\hline Public & 3 & $60 \%$ & 29 & $65.9 \%$ & \\
\hline \multirow[t]{4}{*}{ Total } & 5 & $100 \%$ & 44 & $100 \%$ & \\
\hline & \multicolumn{4}{|c|}{ Toxicant contamination in snacks } & $p$ \\
\hline & \multicolumn{2}{|l|}{ Positive } & \multicolumn{2}{|c|}{ Negative } & \\
\hline & Total & $\%$ & Total & $\%$ & \\
\hline Private & 9 & $32.1 \%$ & 1 & $6.2 \%$ & 0.067 \\
\hline Public & 19 & $67.9 \%$ & 15 & $93.8 \%$ & \\
\hline Total & 28 & $100 \%$ & 16 & $100 \%$ & \\
\hline
\end{tabular}

Based on the test results using chi square test, it was obtained $p>0.05$, so it can be concluded that there is no difference between microbial and toxicant contamination in school snacks and cooking utensils with their status.

\section{Discussion}

The results of this study were obtained from secondary data from Surabaya City Health Office in the form of test results of $E$. coli contamination on snacks and cooking utensils, as well as toxicant contamination in snacks. To parse the results of this study, these results were compared with existing regulations and research.

\section{Standards for $E$. coli and Toxicant Inspections}

According to POM Regulation No. 16 of 2016 regarding the standard of microbe test on snacks, several standards have been set. The following are the standards for some foods tested by the Surabaya DKK using the POM standards. ${ }^{10}$ Each food inspection has different standards and different analysis techniques. What was tested by the DKK was $E$. coli, because to check all microbes according to food standards it required a lot of time, effort, and cost, while the area and schools in Surabaya were very large. That was why DKK took one indicator, namely $E$. coli.

In addition to microbiological contamination, there was also contamination of toxicant which was also tested by DKK Surabaya. According to Minister of Health Regulation no. 722 of 1988 regarding food additives, various maximal standards of food additives that may be used have been mentioned. Borax, Rhodamine $\mathrm{B}$, and formalin contain additives which are prohibited from being used in food. Standards for examining various chemicals in food and beverages have been described in Minister of Health Regulation no. 722 of 1988. From these tests, the results were mentioned with positive and negative criteria contaminated with toxicant material.

The criteria for $E$. coli contamination in cooking utensils are judged by the presence of these bacteria in the tools used by canteen sellers for cooking. The tools used for cooking snacks can come from the water used to wash the tool. Water contaminated with E. coli bacteria in cooking utensils indicates that sanitation and cleanliness are not good. ${ }^{11}$

\section{Relationship between E. coli Contamination in Snacks and Cookware and Toxicant in Snacks for School Areas}

In the results of this study it was stated that there was no significant relationship between the area with good $E$. coli contamination in snacks and cooking utensils, and toxicant contamination in snacks. The area in Surabaya is relatively homogeneous, so the area is not a factor that influences contamination results. This has been reviewed in a study. The results of the study stated that there was no relationship between the place of food sales and $E$. coli contamination. This is because many sellers still maintain environmental sanitation around the place. However, this still needs to be explored further with other causative factors. ${ }^{12}$ It can be concluded from these two studies that the region does not affect $E$. coli contamination in snacks and cooking utensils, and toxicant contamination in snacks.

\section{Relationship between E. coli Contamination in Snacks} and Cookware and Toxicant in Snacks to School Status

In one research in Nigeria, school health program was to promote and prevent the students' health and could be expanded to improve the surrounding people. In that research, it was found that private school had better school health program than the public school. ${ }^{13}$ In another study it 
was found that the private school had a higher score than the public school when they gave the training of BLS and AED in six months. ${ }^{14}$ In this study it is known that there is no relationship between $E$. coli contamination in snacks and cookware and toxicant in snacks to school status, even though in the descriptive data it is found that public school have more contamination than the private school. Perhaps school in the city is different with school in those country with their curriculum, control, and management.

\section{Impact of $E$. coli and Toxicant Contamination}

Food contaminated with $E$. coli and toxicant, and cooking utensils contaminated with $E$. coli can produce adverse effects. There are various negative effects of toxicant use on food. The first is Rhodamine B. In the long term, the use of this substance can cause impaired liver function and cancer. From several studies that have been done on mice with the use of these dyes, the result turns out that changes in liver cells from normal to necrosis are characterized by picnotics and nucleus hyperpicnotics, fat degeneration, limits cells which are not clear because the cytoplasm undergoes cytolysis. The damage is proportional to the dosage given. ${ }^{4}$ In addition to liver damage, administration of Rhodamine B in mice causes glomerular damage according to the dose and duration of administration. The damage is in the form of bowman space constriction in the glomerulus, hypertrophy, necrosis, and tubular cirrhosis. ${ }^{5}$

Then the next ingredient is borax. Symptoms of borax poisoning are nausea, vomiting, diarrhoea, stomach cramps, erythema spots and rashes on the skin, decreased body temperature, weakness, anxiety, and kidney damage. Prolonged use can cause fever, anorexia, anuria, kidney damage, depression, and confusion. ${ }^{6}$

The next dangerous ingredient is formalin. Formalin is easily absorbed by the body through breathing and easily causes health problems. The formaldehyde component that is not metabolized will form a stable cross-link with the DNA protein gene and this bond will cause a chaotic genetic information system that can cause cancer and genetic mutations. $^{2}$

The large number of chemical pollutants in this era also contribute to the occurrence of cancer due to the instability of the genome. Small but continuous exposure can trigger cancer indirectly by affecting genome stability. ${ }^{15}$ Exposure to these chemicals can also have a significant effect on biological systems because they can interfere with normal perforation patterns and cause susceptibility to a disease. ${ }^{3}$

Meanwhile, the negative effects of $E$. coli contamination are as follows: $E$. coli which can cause diarrhoea is very varied $^{7}$. The impact of consuming unsafe foods will cause health problems. These health problems vary, from mild symptoms such as nausea, vomiting, stomach and muscle cramps, diarrhoea to death. ${ }^{8}$

\section{Conclusion}

There is no relationship between $E$. coli and toxicant contamination in primary school canteen food based on region and level in Surabaya, but it is needed to enhance the supervision of the school especially for primary school to increase healthy food in school canteen.

\section{CONFLICT OF INTEREST}

The author stated there is no conflict of interest in this study.

\section{REFERENCES}

1.Indonesia KKR. Situasi Pangan Jajanan Anak Sekolah. Jakarta: Pusat Data dan Informasi Kementerian Kesehatan Republik Indonesia, 2015.

2.Kristianto Y, Riyadi BD and Mustafa A. Faktor Determinan Pemilihan Makanan Jajanan pada Siswa Sekolah Dasar. 2013. 2013: 6.

3.Schug TT, Janesick A, Blumberg B and Heindel JJ. Endocrine Disrupting Chemicals and Disease Susceptibility. The Journal of Steroid Biochemistry and Molecular Biology. 2011; 127: 204-15.

4.Yamlean PV. Identifikasi dan Penetapan Kadar Rhodamin B pada Jajanan Kue Berwarna Merah Muda yang Beredar di Kota Manado. Jurnal IImiah Sains. 2011; 11: $290-5$.

5.Mayori R, Marusin N and Tjong DH. Pengaruh Pemberian Rhodamin B terhadap Struktur Histologis Ginjal Mencit Putih (Mus musculus L.). Jurnal Biologi Universitas Andalas. 2013; 2: 43-9.

6.Payu M. Analisis Boraks pada Mie Basah yang Dijual di Kota Manado. Pharmacon, 2014.

7.Jafari A, Aslani MM and Bouzari S. Escherichia Coli: A Brief Review of Diarrheagenic Pathotypes and Their Role in Diarrheal Diseases in Iran. Iran J Microbiol. 2012; 4: 102-17.

8.Indonesia KKR. Pedoman Keamanan Pangan di Sekolah Dasar. Jakarta: Pusat Data dan Informasi Kementerian Kesehatan Republik Indonesia, 2011.

9.Drummond C and Sheppard L. Examining Primary and Secondary School Canteens and Their Place within the School System: A South Australian Study. Health Education Research. 2011; 26: 739-49.

10.Indonesia BPODMR. 5 Kunci Keamanan Pangan: (2012).

11.Kobis IW, Umboh JM and Pijoh VD. Gambaran Keberadaan Escherichia Coli pada Peralatan Makan di Rumah Makan Pasar Bersehati Kota Manado. Manado: Universitas Sam Ratulangi, 2013.

12.Kurniasih RP, Nurjazuli N and Hanani D. Y. Hubungan Higiene dan Sanitasi Makanan dengan Kontaminasi Bakteri Escherichia Coli dalam Makanan di Warung Makan Sekitar Terminal Borobudur, Magelang. 2015. 2015; 3: 10.

13.Kuponiyi OT, Amoran OE and Kuponiyi OT. School Health Services and Its Practice Among Public and Private Primary Schools in Western Nigeria. BMC Research Notes. 2016; 9: 203-.

14.Fernandes JM, Leite AL, Auto BDE S, Lima JE, Rivera IR and Mendonca MA. Teaching Basic Life Support to Students of Public and Private High Schools. Arq Bras Cardiol. 2014; 102: 593-601.

15.Langie SA, Koppen G, Desaulniers D, et al. Causes Of Genome Instability: The Effect of Low Dose Chemical Exposures in Modern Society. Carcinogenesis. 2015; 36 Suppl 1: S61-88. 